\title{
PENGARUH KUALITAS PRODUK DAN KUALITAS PELAYANAN TERHADAP LOYALITAS PELANGGAN DENGAN KEPUASAN PELANGGAN SEBAGAI VARIABEL INTERVENING PADA BENGKEL SISAM PEMATANGSIANTAR
}

\author{
Oleh: \\ Risky Ananda \\ S1 Manajemen \\ Darwin Lie, Marisi Butarbutar, Ady Inrawan
}

\begin{abstract}
ABSTRAK
Tujuan penelitian ini adalah: 1. Untuk mengetahui gambaran kualitas produk, kualitas pelayanan, loyalitas pelanggan dan kepuasan pelanggan pada Bengkel Sisam Pematangsiantar. 2. Untuk mengetahui pengaruh kualitas produk dan kualitas pelayanan terhadap kepuasan pelanggan pada Bengkel Sisam Pematangsiantar secara simultan. 3. Untuk mengetahui pengaruh kualitas produk dan kualitas pelayanan terhadap kepuasan pelanggan pada Bengkel Sisam Pematangsiantar secara parsial. 4. Untuk mengetahui pengaruh kepuasan pelanggan terhadap loyalitas pelanggan pada Bengkel Sisam Pematangsiantar. Desain penelitian yang digunakan adalah penelitian kepustakaan dari penelitian lapangan. Data yang digunakan dalam penelitian adalah data kualitatif dan data kuantitatif. Sumber data adalah data primer dan data sekunder. Populasi pada penelitian ini adalah pelanggan Bengkel Sisam Pematangsiantar yang berjumlah 40 orang. Pengumpulan data dilakukan dengan wawancara, kuesioner dan dokumentasi. Teknik analisis yang digunakan adalah analisis regresi linier berganda dan sederhana, koefisien korelasi, koefisien determinasi, dan pengujian hipotesis.

Hasil penelitian dapat disimpulkan sebagai berikut: 1. Kualitas produk sangat baik, kualitas pelayanan baik, kepuasan pelanggan puas dan loyalitas pelanggan tinggi. 2. Terdapat pengaruh yang positif antara kualitas produk dan kualitas pelayanan dengan kepuasan pelanggan dibuktikan dengan regresi $\hat{Y}=3,781+0,180 X_{1}+0,256 X_{2}$. Terdapat pengaruh yang positif antara kepuasan pelanggan terhadap loyalitas pelanggan dibuktikan dengan regresi $\hat{Y}=5,987+1,157$ X. 3 . Terdapat hubungan yang tinggi dan positif antara kualitas produk dan kualitas pelayanan dengan kepuasan pelanggan dibuktikan dengan $\mathrm{r}=0,821$ dan $\mathrm{R}$ Square $=0,674$. Terdapat hubungan yang kuat antara kepuasan pelanggan dengan loyalitas pelanggan dibuktikan dengan $r=0,818$ dan $R$ Square $=0,670$. 4. Hasil hipotesis $\mathrm{H}_{0}$ ditolak, artinya kualitas produk dan kualitas pelayanan berpengaruh positif dan signifikan terhadap loyalitas pelanggan dengan kepuasan pelanggan sebagai variabel intervening baik secara simultan maupun parsial.
\end{abstract}

Kata Kunci: Kualitas Produk, Kualitas Pelayanan, Kepuasan Pelanggan dan Loyalitas Pelanggan

\section{ABSTRACT}

The purpose of research is: 1. Description of product quality, service quality, customer loyalty and customer satisfaction on Lathe Workshop Sisam Pematangsiantar. 2. The influence of product quality and service quality againts customer satisfaction on Lathe Workshop Sisam Pematangsiantar simultaneously. 3. The influence of product quality and service quality againts customer satisfaction on Lathe Workshop Sisam Pematangsiantar partially. 4. The influence customer satisfaction againts customer loyalty on Lathe Workshop Sisam Pematangsiantar. Design research is the research library and field research. The data type used is qualitative and quantitative and data. Data sources are primary data and secondary data. The population in this research is the customer Lathe Workshop Sisam Pematangsiantar of 40 people. Data collection is done with the interview, questionnaire and the documentation. Analytical techniques used was multiple linier regression analysis and simple, correlation coefficient, coefficient of determination, and hypothesis testing.

Research result can be summed up as follows: 1. Description of product quality are very well, well service quality, customer satisfaction satisfied and customer loyalty well. There is a positive influence between product quality and service quality toward customer satisfaction evidenced by the regression $\hat{Y}=3,781+0,180 X_{1}+0,256$ $X_{2}$. 2. There is a positive influence between customer satisfaction toward customer loyalty evidenced by the regression $\hat{Y}=5,987+1,157 X$ 3. There is moderately high and positive correlation between product quality and service quality with customer satisfaction evidenced by $r=0,821$ and $R$ Square $=0,674$. There is high and positive correlation between customer satisfaction with customer loyalty is evidenced by the $r=0,816$ and $R$ Square $=$ 0,670. 4. The results of the hypothesis $H_{0}$ is rejected, meaning that product quality and service quality a positive and significant effect against the customer loyalty with the customer satisfaction simultaneously intervening variables as well as partial.

Keyword: product quality, service quality, customer satisfaction and customer loyalty. 


\section{A. PENDAHULUAN}

\section{Latar Belakang Masalah}

Bengkel Sisam merupakan bengkel bubut yang tidak hanya untuk mereparasi mesin melainkan untuk memodifikasi mesin sepeda motor, yang kegiatan usahanya memerlukan mesin bubut. Penggunaan mesin bubut juga tak lepas dari mesin gerinda, mesinfrais, dan mesin lainnya guna memberikan pelayanan yang terbaik dan menumbuhkan kesetiaan pelanggan terhadap perusahaan.

Loyalitas pelanggan merupakan hal yang sangat penting bagi perusahaan. Bengkel Sisam selalu berusaha mengembangkan dan mempertahankan loyalitas pelanggannya. Adapun fenomena loyalitas pelanggan yang terjadi pada Bengkel Sisam Pematangsiantar dapat dilihat dari hasil wawancara dengan pimpinan yaitu sebagai berikut:

Tabel 1

Fenomena Loyalitas Pelanggan Pada Bengkel Sisam Pematangsiantar

\begin{tabular}{|c|c|c|c|c|c|c|}
\hline $\begin{array}{c}\text { Karakteristik } \\
\text { Loyalitas } \\
\text { Pelanggan } \\
\end{array}$ & ST & $\mathbf{T}$ & $\mathbf{S}$ & $\mathbf{R}$ & SR & Total \\
\hline $\begin{array}{l}\text { Melakukan } \\
\text { Pembelian } \\
\text { Berulang } \\
\end{array}$ & $\begin{array}{l}30 \\
\%\end{array}$ & $\begin{array}{l}55 \\
\%\end{array}$ & $\begin{array}{l}15 \\
\%\end{array}$ & $\begin{array}{c}0 \\
\%\end{array}$ & $0 \%$ & $100 \%$ \\
\hline $\begin{array}{l}\text { Membeli Antar } \\
\text { Lini Produk dan } \\
\text { Jasa }\end{array}$ & 35 & $\begin{array}{l}40 \\
\%\end{array}$ & $\begin{array}{l}25 \\
\%\end{array}$ & $\begin{array}{c}0 \\
\%\end{array}$ & $0 \%$ & $100 \%$ \\
\hline $\begin{array}{l}\text { Merekomendasi } \\
\text { kan Kepada } \\
\text { Orang Lain }\end{array}$ & $\begin{array}{l}40 \\
\%\end{array}$ & $\begin{array}{l}40 \\
\%\end{array}$ & $\begin{array}{l}20 \\
\%\end{array}$ & $\begin{array}{c}0 \\
\%\end{array}$ & $0 \%$ & $100 \%$ \\
\hline $\begin{array}{l}\text { Menunjukan } \\
\text { Kekebalan } \\
\text { Terhadap } \\
\text { Pesaing } \\
\end{array}$ & $\begin{array}{l}35 \\
\%\end{array}$ & $\begin{array}{l}45 \\
\%\end{array}$ & $\begin{array}{l}20 \\
\%\end{array}$ & $\begin{array}{c}0 \\
\%\end{array}$ & $0 \%$ & $100 \%$ \\
\hline Rata-rata & $\begin{array}{l}35 \\
\%\end{array}$ & $\begin{array}{l}45 \\
\%\end{array}$ & $\begin{array}{l}20 \\
\%\end{array}$ & $\begin{array}{c}\mathbf{0} \\
\%\end{array}$ & $0 \%$ & $100 \%$ \\
\hline
\end{tabular}

Sumber: wawancara dengan pimpinan Bengkel Sisam Pematangsiantar (Juli 2017)

Pada tabel 1 di atas diketahui bahwa loyalitas pelanggan pada bengkel Sisam Pematangsiantar belum optimal, hal ini dapat dilihat dari kategori sedang dengan hasil 15\% pada dimensi melakukan pembelian berulang. Dimana masih terdapat pelanggan yang masih berpindah-pindah dalam mereparasi mesin. Pada dimensi membeli antar lini produk dan jasa diperoleh persentase terendah sebesar 25\%. Hal ini disebabkan, karena masih ada pelanggan yang mereparasi mesin membawa sparepart sendiri.

Pada dimensi merekomendasikan kepada orang lain diperoleh hasil persentase $20 \%$, hal ini dikarenakan adanya pelanggan yang tidak ingin memberitahukan kepada rekan kerja dan keluarganya untuk mereparasi mesin ke Bengkel Sisam Pematangsiantar. Sedangkan pada dimensi menunjukan kekebalan terhadap pesaing diperoleh hasil persentase $20 \%$, hal ini disebabkan karena masih terdapat pelanggan yang tidak konsisten untuk melakukan reparasi mesin pada Bengkel Sisam Pematangsiantar.

Salah satu loyalitas pelanggan dapat dilihat dari seberapa besar kepuasan pelanggan terpenuhi. Bengkel Sisam selalu berusaha menunjukan keunggulannya dalam memenuhi kepuasan pelanggan, Dimensi kepuasan pelanggan pada Bengkel Sisam diketahui berdasarkan emosi, harga dan promosi. Adapun fenomena kepuasan pelanggan pada Bengkel Sisam Pematangsiantar belum optimal.

Dari pengamatan penulis kepuasan pelanggan yang kurang optimal terjadi pada dimensi emosi, hal ini dapat dilihat penulis dari pelanggan yang masih ada kecewa yang dapat dilihat atas komplain suatu barang yang digunakannya. Pada dimensi harga, masih terdapat para pelanggan yang menawar harga yang diberikan Bengkel Sisam. Pada dimensi promosi, masih ada beberapa pelanggan yang menanyakan barang yang memiliki promo, hal ini dapat dilihat dari pelanggan yang meminta diskon untuk mencari keuntungan kembali pada pihak yang memiliki sepeda motor.

Diduga kepuasan pelanggan terjadinya karena adanya kualitas produk. Bengkel Sisam akan senantiasa berusaha melakukan pengawasan yang intensif terhadap komponen bahan dasar produk, proses produksi, maupun produk akhir untuk menjaga kualitas produk. Adapun dimensi yang digunakan untuk mengukur kualitas produk yang meliputi: kinerja, keistimewaan, kehandalan, kesesuaian dengan spesifikasi, daya tahan, kemampuan pelayanan, estetika dan kualitas yang dipersiapkan.

Pada dimensi kinerja penulis mengemukakan fenomena yang terjadi yaitu masih terdapat para mekanik yang kurang teliti dalam menyelesaikan pekerjaannya. Pada dimensi keistimewaan penulis mengemukakan fenomena yaitu Bengkel Sisam belum mampu memenuhi keinginan pelanggan sesuai dengan perubahan pasar dalam dunia modifikasi otomotif yang terjadi sudah hampir berjalan dua tahun. Hal ini dikarenakan kurangnya pengetahuan yang semakin tahun berganti dan peralatan mesin yang canggih. Pada dimensi kehandalan penulis mengemukakan fenomena yaitu masih terdapat mesin yang tidak dapat beroperasi dengan cepat yang mengakibatkan sepeda motor tidak memiliki tingkat kecepatan yang tinggi, hal ini terjadi karena masih terjadi kesalahan mekanik dalam teknis.

Pada dimensi kesesuaian dengan spesifikasi, penulis mengemukakan fenomena yang terjadi yaitu masih terdapat beberapa produk spare part sepeda motor tidak memenuhi standart kualitas yang telah di informasikan pada pembungkus spare part. Pada dimensi daya tahan, masih ada beberapa produk yang dipulangkan pelanggan dalam waktu tiga bulan, hal ini bisa terjadi karena daya tahan suatu produk belum optimal. Pada dimensi kemampuan pelayanan penulis mengemukakan fenomena yang terjadi yaitu karyawan masih belum mampu mengenal kode barang spare part. Pada dimensi estetika penulis mengemukakan fenomena yang terjadi, yaitu masih terjadinya kesalahan mekanik dalam kerapian proses pembubutan yang mengakibatkan berkurangnya daya tarik produk. Pada dimensi kualitas yang dipersiapkan penulis mengemukakan fenomena yang terjadi, yaitu masih terdapat beberapa bahan baku besi tuangan baja yang kurang baik kualitasnya.

Selain itu, kepuasan pelanggan ditentukan oleh kualitas pelayanan. Kualitas pelayanan memberikan suatu dorongan kepada konsumen untuk menjalin ikatan hubungan yang kuat dengan perusahaan. Bengkel Sisam berusaha memberikan pelayanan yang terbaik kepada pelanggannya, untuk memenuhi standar pelayanan yang optimal. Kualitas pelayanan yang diberikan Bengkel Sisam meliputi: bukti fisik, kehandalan, ketanggapan, jaminan dan empati. 
Pada dimensi bukti fisik fenomena yang terjadi pada Bengkel Sisam yaitu kurangnya penambahan mesin pembubutan yang lebih canggih dalam mereparasi mesin. Pada dimensi kehandalan fenomena yang terjadi pada Bengkel Sisam yaitu masih terjadinya antrian pada pelanggan yang memakan waktu hingga tiga atau lima jam. Hal ini terjadi dikarenakan kurangnya karyawan pada Bengkel Sisam Pematangsiantar. Pada dimensi ketanggapan, penulis mengemukakan fenomena yang terjadi yaitu adanya karyawan yang tidak secara baik menanggapi keluhan dan keinginan pelanggan. Pada dimensi jaminan penulis mengemukakan fenomena yang terjadi yaitu pelanggan merasa senang dan yakin atas reparasian mesin yang diberikan Bengkel Sisam karena pimpinan memberikan jaminan barang yang direparasi oleh karyawanya dalam waktu yang telah ditentukan. Pada dimensi emphaty, dimana pelanggan sangat sulit menjelaskan masalah yang telah dihadapinnya kepada mekanik, hal ini dapat terjadi karena banyaknya pekerjaan mekanik sehingga sulitnya bagi pelanggan untuk mengutarakan keluhan.

Berdasarkan latar belakang yang telah penulis uraian diatas, maka penulis tertarik untuk melakukan penelitian dengan judul: Pengaruh Kualitas Produk dan Kualitas Pelayanan Terhadap Loyalitas Pelanggan dengan Kepuasan Pelanggan Sebagai Variabel Intervening Pada Bengkel Sisam Pematangsiantar.

\section{Rumusan Masalah}

a. Bagaimana gambaran kualitas produk, kualitas pelayanan, loyalitas pelanggan dan kepuasan pelanggan pada Bengkel Sisam Pematangsiantar.

b. Bagaimana pengaruh kualitas produk dan kualitas pelayanan terhadap kepuasan pelanggan pada Bengkel Sisam Pematangsiantar secara simultan.

c. Bagaimana pengaruh kualitas produk dan kualitas pelayanan terhadap kepuasan pelanggan pada Bengkel Sisam Pematangsiantar secara parsial.

d. Bagaimana pengaruh kepuasan pelanggan terhadap loyalitas pelanggan pada Bengkel Sisam Pematangsiantar.

\section{Tujuan Penelitian}

a. Untuk mengetahui gambaran kualitas produk, kualitas pelayanan, loyalitas pelanggan dan kepuasan pelanggan pada Bengkel Sisam Pematangsiantar.

b. Untuk mengetahui pengaruh kualitas produk dan kualitas pelayanan terhadap kepuasan pelanggan pada Bengkel Sisam Pematangsiantar secara simultan.

b. Untuk mengetahui pengaruh kualitas produk dan kualitas pelayanan terhadap kepuasan pelanggan pada Bengkel Sisam Pematangsiantar secara parsial.

c. Untuk mengetahui pengaruh kepuasan pelanggan terhadap loyalitas pelanggan pada Bengkel Sisam Pematangsiantar.

\section{Metode Penelitian}

Lokasi atau tempat penelitian ini dilakukan di Bengkel Sisam Pematangsiantar yang berada di Jalan Sriwijaya No.106 Pematangsiantar. Pada penelitian ini yang menjadi populasi adalah pelanggan Bengkel Sisam Pematangsiantar sebanyak 40 orang. Seluruh pelanggan yang berjumlah 40 orang akan menjasi sampel sebagai responden untuk menjawab kuesioner yang penulis sebarkan.

Adapun desain penelitian yang digunakan dalam penulisan skripsi ini adalah penelitian kepustakaan (Library Research)dan penelitian lapangan (Field Research). Teknik pengumpulan data yang dilakukan penulis dalam penelitian ini adalah berupa kuesioner, wawancara, dokumentasi dan observasi. Adapun jenis data yang dilakukan dalam penelitian ini adalah jenis jenis data kualitatif dan kuantitatif. Hasil data yang diperoleh dari lapangan akan dianalisis secara deskriptif baik bersifat kualitatif dan kuantitatif.

\section{B. LANDASAN TEORI}

\section{Manajemen dan Manajemen Pemasaran}

Menurut Stoner dalam Handoko (2009:8), manajemen adalah proses perencanaan, pengorganisasian, pengarahan, dan pengawasan usaha-usaha para anggota organisasi dan penggunaan sumber daya-sumber daya organisasi lainnya agar mencapai tujuan organisasi yang telah ditetapkan. Menurut Kotler dan Kevin (2009:5), manajemen pemasaran adalah seni dan ilmu memilih pasar sasaran dan meraih, mempertahankan, serta menumbuhkan pelanggan dengan menciptakan, menghantarkan, dan mengomunikasikan nilai pelanggan yang unggul.

a. Plaining

Menurut Robbins dan Mary (2005:9), manajemen memiliki beberapa fungsi yaitu:

Menyusun dan merencanakan strategi untuk mencapai tujuan tersebut, dan membuat rencana-rencana untuk mengintegrasikan dan mengkoordinasikan aktivitas-aktivitas.

b. Organizing

Menentukan pekerjaan yang harus dilakukan, siapa yang melakukan, dan bagaimana pekerjaan dikelompokkan, kepada siapa pekerjaan dilaporkan dan bagaiman keputusan dibuat.

c. Leading

Menengahkan konflik kelompok, memotivasi bawahan, mempengaruhi individu-individu atau kelompok, dan memilih komunikasi yang akan digunakan.

d. Controlling

Mengawasi aktivitas-aktivitas demi memastikan segala sesuatunya terselesaikan sesuai rencana dan aktifitas karyawan, pertahanan organisasi pada jalur pemenuhan tujuan, dan pengkoreksian bila diperlukan.

\section{Kualitas Produk}

Menurut Tjiptono (2008:213), bahwa kualitas produk merupakan perpaduan antara sifat dan karakteristik yang menentukan sejauh mana keluaran dapat memenuhi prasyarat kebutuhan pelanggan atau menilai sampai seberapa jauh sifat dan karakteristik itu memenuhi kebutuhannya. Menurut Lupiyoadi dan Hamdani (2001:158), kualitas produk adalah konsumen akan merasa puas bila hasil evaluasi mereka menunjukan bahwa produk yang mereka gunakan berkualitas. berikut:

Menurut Kotler dan Gary (2008:347), dimensi dari kualitas produk yang dapat digunakan adalah sebagai 
a. Performance (kinerja)

Yaitu berhubungan dengan perspektif fungsional dari produk dan merupakan karakteristik utama yang dipertimbangkan pelanggan ketika ingin membeli suatu produk.

b. Features (keistimewaan)

Yaitu merupakan aspek kedua dari performa yang menambah fungsi dasar yang berkaitan dengan pilihanpilihan dengan perkembangannya.

c. Reliability (Kehandalan)

Yaitu berkaitan dengan kemungkinan suatu produk melaksanakan fungsinya secara berhasil dalam periode waktu tertentu dibawah kondisi tertentu.

d. Conformance to spesification (kesesuaian dengan spesifikasi)

Yaitu sejauh mana karakteristik desain dan operasi memenuhi standar yang telah ditetapkan sebelumnya berdasarkan keinginan pelanggan.

e. Durability (daya tahan)

Yaitu merupakan ukuran masa pakai suatu produk, berkaitan dengan daya tahan produk itu.

f. $\quad$ Service ability (kemampuan pelayanan)

Yaitu merupakan karakteristik yang berkaitan dengan kecepatan, keramahan, atau kesopanan, kompetensi, kenyamanan, mudah direparasi, serta penanganan keluhan yang memuaskan.

g. $\quad$ Aesthetics (estetika)

Yaitu daya tarik produk terhadap panca indera, seperti bentuk fisik, warna, dan sebagainya.

h. Perceived quality (kualitas yang dipersepsikan)

Yaitu citra dan reputasi produk serta tanggung jawab perusahaan terhadap kualitas ini bersifat subjektif, berkaitan dengan perasaan pelanggan dalam mengkonsumsi produk tersebut.

\section{Kualitas Pelayanan}

Menurut Tjiptono (2008:7), pelayanan merupakan kegiatan, manfaat, atau kepuasan yang ditawarkan untuk dijual. Dalam dunia pemasaran, kepuasan konsumen menjadi tolak ukur dalam keberhasilan pelayanan. Manifestasi perilaku produsen merupakan refleksi layanan dalam rangka memenuhi kebutuhan dan keinginan konsumen demi tercapainya kepuasan pada konsumen itu sendiri. Kemudian menurut Kotler dan Gary (2008:266), pelayanan adalah semua kegiatan atau manfaat yang dapat ditawarkan suatu pihak kepada pihak lain, yang pada dasarnya tak berwujud (intangible) dan tidak menghasilkan kepemilikan sesuatu.

Sedangkan menurut Irawan (2004:58), dimensi kualitas pelayanan meliputi:

1) Tangibles (bukti fisik)

Bukti fisik merupakan suatu service yang bisa dilihat, bisa dicium, dan bisa diraba, maka aspek tangible menjadi penting sebagai ukuran terhadap pelayanan. Pelanggan akan menggunakan panca indera untuk menilai suatu kualitas pelayanan.

2) Reability (Kehandalan)

Yaitu dimensi yang sering dipersepsikan paling penting bagi pelanggan dari berbagai industri jasa. Dimensi kehandalan merupakan dimensi untuk mengukur kehandalan dari perusahaan dalam memberikan pelayanan kepada pelanggannya.

3) Reponsiveness (ketanggapan)

Yaitu dimensi kualitas pelayanan yang paling dinamis. Dimensi ini pada umumnya merupakan harapan pelanggan terhadap kecepatan pelayanan hampir dapat dipastikan akan berubah dengan cenderungan naik dari waktu ke waktu.

4) Assurance (jaminan)

Yaitu dimensi kualitas yang berhubungan dengan kemampuan perusahaan dalam menanamkan rasa percaya dan keyakinan kepada para pelanggannya.

5) Emphaty (empati)

yaitu bahwa perusahaan memahami masalah para pelanggannya dan bertindak demi kepentingan pelanggan, serta memberikan perhatian personal kepada para pelanggan.

\section{Kepuasan Pelanggan}

Menurut Day dalam Tjiptono (2008:24), kepuasan pelanggan adalah respon pelanggan terhadap evaluasi ketidak sesuaian yang dirasakan antara harapan sebelumnya dan kinerja aktual produk yang dirasakan setelah pemakaiannya. Sedangkan menurut Gerson (2002:112), kepuasan pelanggan adalah persepsi bahwa harapan telah terpenuhi atau terlampaui dan tetap lanjut berhubungan dengan perusahaan, dan sebaliknya jika pelanggan tidak puas, dia akan menghentikan bisnisnya dengan perusahaan.

Menurut Lupiyoadi dan Hamdani (2001:158), menyatakan bahwa ada lima dimensi kepuasan pelanggan, antara lain:

1) Kualitas produk

Yaitu perasaan puas yang ditunjukkan oleh pelanggan bila produk yang mereka gunakan berkualitas.

2) Kualitas Pelayanan atau jasa

Yaitu perasaan puas yang diekspresikan oleh pelanggan bila mereka mendapatkan pelayanan yang baik atau sesuai dengan yang diharapkan.

3) Emosi

Yaitu kepuasan yang diperoleh bukan karena kualitas dari produk tetapi sosial atau self esteem yang membuat pelanggan merasa puas terhadap merek tertentu. Pada umumnya pelanggan akan memperoleh keyakinan bahwa orang lain akan kagum terhadap dia bila menggunakan produk dengan merek tertentu yang cenderung mempunyai tingkat kepuasan yang lebih tinggi.

4) Harga

Yaitu menetapkan harga yang relatif murah akan memberikan nilai yang lebih tinggi kepada pelanggan dengan produk yang mempunyai kualitas yang sama.

5) Promosi

Yaitu promosi mengenai informasi produk dan jasa perusahaan dalam usaha mengkomunikasikan manfaat produk dan jasa pada konsumen sasaran. Kegiatan promosi ini meliputi iklan produk dan jasa, diskon barang 
dan pemberian hadiah.

\section{Loyalitas Pelanggan}

Menurut Griffin (2003:31), loyalitas konsumen adalah melakukan pembelian berulang secara teratur, membeli antar lini produk dan jasa, mereferensikan kepada orang lain, menunjukan kekebalan terhadap tarikan kepada pesaing. Menurut Lupiyoadi dan Hamdani (2006:193), loyalitas adalah komitmen yang dipegang kuat untuk membeli ulang atau berlangganan lagi produk atau jasa tertentu dimasa depan meskipun ada pengaruh situasi yang menyebabkan peralihan perilaku.

Menurut Griffin (2004:31), berikut ada beberapa dimensi loyalitas berdasarkan perilaku konsumen yakni:

1) Melakukan pembelian ulang secara teratur

Kesediaan untuk terus memperpanjang hubungan dan terus menggunakan produk/jasa yang ditawarkan perusahaan.

2) Membeli antar lini produk dan jasa

Menggunakan produk lain yang diproduksi atau ditawarkan oleh perusahaan kita, meskipun produknya berbeda-beda.

3) Merekomendasikan kepada orang

Menjadi orang penganjur dan mereferensikan kepuasannya dan kebaikan produk/jasa perusahaan kepada pihak lain untuk segera menggunakan produ/jasa perusahaan.

4) Menunjukan kekebalan terhadap pesaing

Konsistensi penggunaan produk/jasa pelayanan perusahaan walaupun terdapat banyak tawaran dari perusahaan pesaing.

\section{PEMBAHASAN}

\section{Analisa}

\section{a. Deskriptif Kualitatif}

Analisis deskriptif kualitatif dimaksudkan untuk mendapatkan gambaran atau deskripsi mengenai kualitas produk, kualitas pelayanan, kepuasan pelanggan dan loyalitas pelanggan pada Bengkel Sisam Pematangsiantar. sesudah pengujian data, maka langkah selanjutnya peneliti melakukan pengkajian analisis kualitatif sebagai gambaran fenomena dari variabel penelitian pada saat sekarang ini. setelah kuesioner diolah, maka nilai-nilai jawaban dari setiap data responden dibagi menjadi beberapa kelas interval.

Adapun penetapan kriteria nilai rata-rata jawaban dari responden tersebut dimasukkan kedalam kelas-kelas penentuan intervalnya memakai rumus sebagai berikut: Interval kelas $=\frac{\text { Nilai tertinggi-Nilai Terendah }}{\text { Jumlah Kelas }}$

Interval $=\frac{5-1}{5}$

Interval $=\frac{4}{5}$

Interval $=0,8$

Kriteria:

a. Nilai Tertinggi adalah $\quad=5$

b. Nilai Terendah adalah $=1$

c. Jumlah Kelas adalah $=5$

Dari rumus diatas dapat diperoleh interval kelas 0,8 sehingga berlaku ketentuan mengenai jawaban responden dengan hasil sebagai berikut:

Tabel 2

Nilai Interval dan Kategori Jawaban Responden

\begin{tabular}{|c|c|}
\hline Nilai Interval & Kategori \\
\hline $1,00-1,80$ & $\begin{array}{c}\text { Sangat Tidak Baik / Sangat } \\
\text { Tidak Puas/ Sangat Rendah/ }\end{array}$ \\
\hline $1,81-2,60$ & $\begin{array}{c}\text { Tidak Baik/ Tidak Puas / } \\
\text { Rendah }\end{array}$ \\
\hline $2,61-3,40$ & $\begin{array}{c}\text { Cukup Baik/ Cukup Puas/ } \\
\text { Rendah }\end{array}$ \\
\hline $3,41-4,20$ & Baik/ Puas/ Tinggi \\
\hline $4,21-5,00$ & $\begin{array}{c}\text { Sangat Baik/ Sangat Puas/ } \\
\text { Sangat Tinggi }\end{array}$ \\
\hline
\end{tabular}

Sumber: hasil pengolahan data (2017)

\section{Kualitas Produk Pada Bengkel Sisam Pematangsiantar}

Kualitas produk merupakan kemampuan suatu produk untuk melakukan fungsi-fungsinya dan keunggulan yang terdapat pada suatu produk. Bila suatu produk telah dapat menjalankan fungsi-fungsinya dapat dikatakan sebagai produk yang memiliki kualitas yang baik. Pada Bengkel Sisam Pematangsiantar, kualitas produk menggunakan delapan dimensi dalam meningkatkan loyalitas antara lain: kinerja, keistimewaan, kehandalan, kesesuaian dengan spesifikasi, daya tahan, kemampuan pelayanan, estetika dan kualitas yang dipersiapkan.

Dari kolom total jawaban dapat dilihat bahwa dimensi kinerja pada indikator aspek fungsional dari produk berada pada rata-rata 4,60 dengan kriteria jawaban sangat baik, hal ini disebabkan karena Bengkel Sisam memberikan produk spare part yang dipasang pada mesin sepeda motor yang sudah terjamin kualitasnya. Pada indikator karakteristik utama suatu produk berada pada rata-rata 4,28 dengan kriteria jawaban sangat baik, hal ini terjadi karena karyawan bagian pembubutan maupun pemboringan mengetahui stelan mesin sepeda motor, karena masing-masing merek sepeda motor berbeda stelan mesinnya. Pada indikator daya guna produk berada pada rata- 
rata 4,20 dengan kriteria jawaban baik, hal ini terjadi karena pada saat pekerjaan berlangsung para karyawan fokus dan teliti baik pada saat pemboringan, pembubutan maupun pemasangan kembali.

Pada dimensi keistimewaan pada indikator penambahan fungsi dasar produk berada pada rata-rata 4,40 dengan kriteria sangat baik, hal ini terjadi karena karyawan memasang berbagai tambahan spare part pada mesin sepeda motor yang ingin dimodifikasi. Pada indikator nilai tambah produk berada pada rata-rata 4,40 dengan kriteria sangat baik, hal ini terjadi karena karyawan Bengkel Sisam melakukan perombaan pada dalam mesin. Pada indikator perkembangan produk berada pada rata-rata 4,05 dengan kriteria baik, hal ini terjadi karena Bengkel Sisam selalu berinovasi dan mengikuti perkembangan otomotif sepeda motor.

Pada dimensi kehandalan pada indikator keberhasilan suatu produk berada pada rata-rata 4,33 dengan kriteria sangat baik, hal ini terjadi karena Bengkel Sisam memberikan reparasian mesin yang memiliki mutu terbaik dan terjamin kualitasnya. Pada indikator kinerja fungsi produk berada pada rata-rata 4,28 dengan kriteria sangat baik, hal ini terjadi karena keahlian mekanik dalam mereparasi mesin menjadikan sepeda motor memiliki kecepatan lebih baik. Pada indikator kehandalan produk berada pada rata-rata 4,48 dengan kriteria sangat baik, hal ini terjadi karena pada saat pemasangan spare part sepeda motor berlangsung diperlukan persiapan yang baik, baik pada spare part yang akan di gunakan, pembubutan yang di persiapkan sampai pemasangan kembali pada sepeda motornya.

Pada dimensi kesesuaian dengan spesifikasi pada indikator kesesuaian produk berada pada rata-rata 4,60 dengan kriteria sangat baik, hal ini dikarenakan keunggulan pada produk yang dipilih pelanggan sesuai dengan penjelasan pada pembungkus spare part. Pada indikator pemenuhan standart produk berada pada rata-rata 4,28 dengan kriteria sangat baik, hal ini dikarenakan Bengkel Sisam memberikan ataupun memasang sparepart mesin sepedamotor yang memiliki standar yang baik serta sudah berstandarisasi nasional. Pada indikator keinginan konsumen berada pada rata-rata 4,20 dengan kriteria baik, hal ini terjadi karena Bengkel Sisam tidak memaksa merek spare part yang akan digunakan pada sepeda motornya melainkan memberikan barang sparepart sesuai dengan keinginan konsumen untuk dipasang pada sepeda motornya.

Pada dimensi daya tahan pada indikator daya tahan produk berada pada rata-rata 4,40 dengan kriteria sangat baik, hal ini dikarenakan Bengkel Sisam tidak terburu-buru dalam menyelesaikan pekerjaannya karena lebih megutamakan kualitas reparasian mesinnya. Pada indikator masa pakai produk berada pada rata-rata 4,40 dengan kriteria sangat baik, hal ini terjadi karena mesin sepeda motor yang direparasi menggunakan suku cadang yang bagus sehingga memiliki masa pakai yang lama setelah direparasi. pada indikator ukuran ketahan berada pada ratarata 4,05 dengan kriteria baik, hal ini terjadi karena keahlian karyawan dalam keberhasilan mereparasi mesin dan didukung oleh spare part yang berkualitas.

Pada dimensi kemampuan pelayanan pada indikator kecepatan pelayanan berada pada rata-rata 4,33 dengan kriteria sangat baik, hal ini terjadi karena karyawan dengan cepat melayani pelanggan yang datang untuk mereparasi mesin sepedamotornya. Pada indikator kompetensi pelayanan berada pada rata-rata 4,28 dengan kriteria sangat baik, hal ini terjadi karena karyawan mampu memahami keinginan pelanggan. Pada indikator keramahan berada pada rata-rata 4,48 dengan kriteria sangat baik, hal ini terjadi karena karyawan selalu memberikan sikap yang baik dan perhatian dalam bentuk membantu pelanggan dalam memberikan solusi untuk mesin sepedamotor yang akan direparsi.

Pada dimensi estetika pada indikator daya tarik produk berada pada rata-rata 4,28 dengan kriteria sangat baik, hal ini dikarenakan karyawan mampu mereparasi mesin sepeda motor dengan rapi selama proses pembubutan yang memudahkan pemasang kembali pada sepeda motor. Pada indikator kemampuan produk berada pada rata-rata 4,35 dengan kriteria sangat baik, hal ini dikarenakan keberhasilan karyawan dalam reparasi mesin membuat mesin menjadi lebih handal dan lincah. Pada indikator kemudahan produk berada pada rata-rata 4,28 dengan kriteria sangat baik, hal ini terjadi karena kerapian kerja karwayan dalam pembubutan membuat mesin yang telah direparasi mudah dipasang kembali oleh para mekanik ataupun pelanggan.

Pada dimensi kualitas yang dipersiapkan pada indikator citra merek berada pada rata-rata 4,23 dengan kriteria sangat baik, hal ini terjadi karena hasi kerja Bengkel Sisam sudah diyakini oleh para pelanggan atas kinerjanya. Pada indikator tanggung jawab perusahaan berada pada rata-rata 4,35 dengan kriteria sangat baik, hal ini terjadi karena Bengkel Sisam memberikan garansi dalam jangka tempo waktu yang sudah ditetapkan atas barang yang telah selesai direparasi. Pada indikator perasaan konsumen berada pada rata-rata 4,20 dengan kriteria baik, hal ini dapat dilihat dari pelanggan yang menunjukan kesenangannya ketika mengendarai sepedamotornya yang telah selesai direparasi.

\section{Kualitas Pelayanan Pada Bengkel Sisam Pematangsiantar}

Kualitas Pelayanan merupakan segala bentuk aktivitas yang dilakukan oleh perusahaan guna memenuhi harapan konsumen dan memberikan pelayanan untuk kepuasan konsumen. Kualitas pelayanan yang diterapkan dalam perusahaan itu sendiri berupa tangible (bukti fisik), reability (kehandalan), responsiveness (ketanggapan), assurance (jaminan), emphaty

Dari kolom total jawaban dapat dilihat bahwa dimensi tangible (bukti fisik) pada indikator perlengkapan mesin berada pada rata-rata 4,18 dengan kriteria baik, hal ini dikarenakan perlengkapan mesin yang digunakan Bengkel Sisam memadai seperti mesin bubut, mesin boringan, mesin frais, mesin bor, serta perlengkapan kuncikunci yang mempermudah dan mempercepat proses perbaikan mesin sepeda motor. Pada indikator kerapian produk berada pada rata-rata 4,10 dengan kriteria baik, hal ini dikarenakan para karyawan mengoptimalkan pekerjaannya ketika mesin sepeda motor berada dalam proses pembubutan dan dilakukan dengan hati-hati sesuai dengan ukuran mesin bubutan agar hasil pekerjaan mereka rapi dan mudah dipasang kembali pada sepeda motor. Pada indikator ketelitian mekanik dalam mereparasi berada pada rata-rata 4,03 dengan kriteria baik, hal ini dapat terjadi karena dalam mereparasi mesin karyawan selalu fokus dan teliti dalam mengerjakan pekerjaannya.

Pada dimensi reability (kehandalan) dengan indikator kehandalan tepat waktu berada pada rata-rata 3,78 dengan kriteria baik, hal ini terjadi karena karyawan mampu menyelesaikan pekerjaannya sesuai jam yang telah disepakati oleh pelanggan. Pada indikator pelayanan yang akurat berada pada rata-rata 3,75 dengan kriteria baik, hal ini terjadi karena karyawan mampu memberikan penjelasan secara detail terhadap pelanggan atas masalah mesin sepeda motor yang akan direparasinya. Pada indikator pelayan yang cepat berada pada rata-rata 4,18 dengan kriteria baik, hal ini dapat terjadi karena karyawan mampu secara cepat melayani pelanggan.

Pada dimensi responsiveness (ketanggapan) dengan indikator respon karyawan berada pada rata-rata 4,18 dengan kriteria baik, hal ini terjadi karena karyawan mampu merespon dan berinteraksi terhadap pelanggan dengan 
baik. Pada indikator kesediaan karyawan dalam membantu pelanggan berada pada rata-rata 4,10 dengan kriteria baik, hal ini terjadi karena karyawan mampu membantu pelanggan untuk mencari barang yang dibutuhkannya terutama pada memilih produk spare part yang akan di gunakan dalam sepedamotornya. Pada indikator pemberian pelayanan berada pada rata-rata 4,03 dengan kriteria baik, hal ini terjadi karena para karyawan Bengkel Sisam selalu berusaha memberikan pelayanan dengan baik dan sopan terhadap pelanggannya.

Pada dimensi assurance (jaminan) yang diamati dengan indikator jaminan barang yang diberikan diperoleh nilai rata-rata 3,78 dengan kriteria baik, hal ini terjadi karena Bengkel Sisam memberikan jaminan barang ketika reparasian mesin sepeda motor rusak kembali dalam jangka waktu tertentu. Pada indikator kemampuan mekanik diperoleh nilai 3,75 dengan kriteria baik, hal ini dapat terjadi karena para tukang bubut memiliki pengetahuan yang baik dan pengalaman yang cukup lama dalam mereparasi mesin sepeda motor. Pada indikator kemampuan administrasi diperoleh nilai rata-rata 3,78 dengan kriteria baik, hal ini terjadi karena kemampuan karayawan bagian administrasi memiliki pengetahuan yang baik dalam pembukuan dan sudah cukup mengenal barang spare part sepeda motor.

Pada dimensi emphaty yang diamati dengan indikator kesediaan karyawan dalam menerima keluhan pelanggan diperoleh nilai rata-rata 4,08 dengan kriteria baik, hal ini terjadi karena karyawan memberikan waktunya terhadap pelanggan yang memiliki keluhan atas mesin sepeda motornya. Pada indikator tanggung jawab terhadap produk yang kembali rusak dalam jangka waktu terdekat diperoleh nilai 3,63 dengan kriteria baik, hal ini dikarenakan pimpinan Bengel Sisam berani bertanggung jawab atas reparasian mesin yang kembali rusak sesuai dengan batas waktu yang telah disepakati. Pada indikator perhatian terhadap kebutuhan pelanggan diperoleh nilai rata-rata 3,53 dengan kriteria baik, hal ini dikarenakan pimpinan Bengkel Sisam selalu bergerak cepat untuk memperhatikan kebutuhan pelanggannya.

\section{Kepuasan Pelanggan Pada Bengkel Sisam Pematangsiantar}

Kepuasan pelanggan yaitu perasaan senang atau kekecewaan pelanggan yang muncul setelah membandingkan kinerja atau hasil produk yang dipikirkan terhadap kinerja akan hasil yang diharapkan. Dengan demikian kepuasan pelanggan sangat penting dalam kelangsungan hidup perusahaan. Pada Bengkel Sisam Pematangsiantar, kepuasan pelanggan menggunakan tiga dimensi antara lain emosi, harga dan promosi.

Dari kolom total jawaban dapat dilihat bahwa dimensi emosi pada indikator rasa percaya yang dimiliki konsumen ketika menggunakan produk/jasa yang diberikan diperoleh nilai rata-rata 4,30 dengan kriteria sangat puas, hal ini dikarenakan karyawan dan pimpinan Bengkel Sisam bekerjasama dalam memberikan kualitas produk yang bermutu dan pelayanan yang baik untuk meningkatkan rasa percaya pelanggan. Pada indikator perasaan konsumen setelah menggunakan produk memperoleh nilai rata-rata 4,25 dengan keriteria sangat puas, hal ini dikarenakan para karyawan dapat memenuhi dan menciptakan produk sesuai keinginan pelanggan yang dapat menimbulkan kesenangan tersendiri bagi pelanggan yang telah mereparasi mesinnya. Pada indikator tercapainya perasaan konsumen mengenai kemampuan produk memperoleh nilai rata-rata 3,90 dengan kriteria puas hal ini terjadi karena keberhasilan karyawan Bengel Sisam dalam mengubah kecepatan sepeda motor lebih cepat dari semulanya.

Pada dimensi harga dengan indikator harga yang diberikan kepada pelanggan diperoleh nilai rata-rata 4,00 dengan kriteria puas, hal ini dikarenakan harga yang diberikan sesuai dengan kualitas diberikan kepada pelanggan. Pada indikator keterjangkauan harga produk spare part diperoleh nilai rata-rata 4,00 dengan kriteria puas, hal ini dikarenakan harga produk yang diberikan Bengkel Sisam masi dalam jangkauan pelanggan. Pada indikator intensitas pemberian diskon memperoleh nilai rata-rata 3,98 dengan kriteria puas, hal ini dikarenakan Bengkel Sisam memberikan potongan harga setiap pembelian spare part.

Pada dimensi promosi dengan indikator pemberian promo diperoleh nilai rata-rata 4,45 dengan kriteria sangat puas, hal ini terjadi karena Bengkel Sisam memberian promo service mesin sepeda motor kepada pelanggan. Pada indikator intensitas pemberian promo berada pada rata-rata 4,38 dengan kriteria sangat puas, hal ini dikarenakan banyaknya pelanggan yang memanfaatkan pemberlakuan promo yang diberikan pimpinan Bengkel Sisam. Pada indikator kuantitas promo memperoleh rata-rata 4,25 dengan kriteria sangat puas, hal ini dikarenakan berbagai macam pemberian promo yang diberikan langsung dari distributor kepada pelanggan.

\section{Loyalitas Pelanggan Pada Bengkel Sisam Pematangsiantar}

Loyalitas pelanggan adalah komitmen pelanggan terhadap suatu merek, toko, pemasok berdasarkan sifat yang sangat positif dan tercermin dalam pembelian ulang yang konsisten, maka dari pada itu loyalitas pelanggan merupakan bukti bahwa konsumen tersebut setia kepada perusahaan dan suatu keinginan konsumen untuk melakukan pembelian berulang-ulang. Pada Bengkel Sisam Pematangsiantar, loyalitas pelanggan menggunakan empat dimensi yaitu melakukan pembelian berulang, membeli antar lini produk dan jasa, merekomendasikan kepada orang lain, dan menunjukan kekebalan terhadap pesaing.

Dari kolom total jawaban dapat dilihat bahwa dimensi melakukan pembelian berulang yang diamati dengan indikator harga diperoleh nilai rata-rata 4,38 dengan kriteria sangat tinggi, hal ini terjadi karena harga yang diberikan Bengkel Sisam kepada pelanggan masih dapat dijangkau oleh pelanggan. Pada indikator diskon diperoleh nilai rata-rata 4,30 dengan kriteria sangat tinggi, hal ini terjadi karena banyaknya potongan harga yang diberikan oleh Bengkel Sisam kepada pelanggannya guna untuk membuat pelanggan lebih tertarik melakukan pembelian berulang. Pada indikator garansi diperoleh nilai rata-rata 4,15 dengan kriteria tinggi, hal ini dikarenakan Bengkel Sisam memberikan tanggung jawab atas pekerjaannya berupa garansi kepada pelanggan setelah mereparasi mesin dalam waktu yang telah ditentukan.

Pada dimensi membeli antar lini produ/jasa yang diamati dengan indikator kelengkapan spare part diperoleh nilai rata-rata 4,18 dengan kriteria tinggi, hal ini dikarenakan Bengkel Sisam menjual berbagai spare part sepeda motor. Pada indikator kelengkapan jenis perawatan atau pembetulan mesin sepeda motor berada pada ratarata 3,98 dengan kriteria tinggi, hal ini dikarenakan Bengkel Sisam memberikan tawaran berbagai reparasian mesin sepeda motor, baik dalam pemasangan kur as, pemboringan, pres segitiga, pres pelak dan masih banyak tawaran reparasiannya. Pada indikator kelengkapan peralatan mesin berada pada rata-rata 4,25 dengan kriteria sangat tinggi, hal ini dikarenakan Bengkel Sisam selalu mengikuti perkembangan mesin pembubutan dan melengkapi berbagai kunci-kunci yang dibutuhkan dalam pekerjaan berlangsung. 
Pada dimensi merekomendasikan kepada orang lain yang diamati oleh indikator promosi berada pada ratarata 4,23 dengan kriteria sangat tinggi, hal ini dikarenakan para pelanggan merasa banyaknya pemberian promosi yang membuat para pelanggan memberitahukan kepada orang lain untuk mereparasi mesin pada Bengkel Sisam. Pada indikator tingkat kepuasan berada pada rata-rata 4,05 dengan kriteria tinggi, hal ini dikarenakan para pelanggan merasa puas atas reparasi mesin sepeda motor dan kemungkinan besar akan mengajak kerabat dan orang lain untuk melakukan reparasi mesin pada Bengkel Sisam. Pada indikator kesopanan diperoleh nilai rata-rata 3,85 dengan kriteria tinggi, hal ini dikarenakan karyawan memberikan sikap dan berbicara yang sopan kepada pelanggan.

Pada dimensi menunjukan kekebalan terhadap pesaing dengan indikator keinginan membeli produk/jasa di satu tempat saja diperoleh nilai rata-rata 4,08 dengan kriteria tinggi, hal ini dikarenakan pelanggan sudah yakin atas kualitas produk dan jasa yang diberikan Bengkel Sisam. Pada indikator kesetiaan untuk tidak berpindah terhadap produk/jasa pesaing diperoleh nilai rata-rata 4,25 dengan kriteria sangat tinggi, hal ini terjadi karena pelanggan telah loyal sejak lama dan telah megetahui keunggulan yang diberikan Bengkel Sisam Pematangsiantar, yang berusaha tidak mengecewakan pelanggannya. Pada indikator percaya terhadap produk/jasa yang ditawarkan memperoleh nilai rata-rata 3,70 dengan kriteria tinggi, hal ini dikarenakan besarnya harapan pelanggan kepada Bengkel Sisam, dan pelanggan mempercayai kinerja dari Bengkel Sisam.

\section{b. Deskriptif Kuantitatif}

\section{1) Analisis Regresi Linier}

a) Pengaruh Kualitas Produk dan Kualitas Pelayanan Terhadap Kepuasan pelanggan.

Penelitian ini memiliki tujuan untuk menganalisis pengaruh kualitas produk dan kualitas pelayanan terhadap kepuasan pelanggan sebagai variabel intervening Pada Bengkel Sisam Pematangsiantar. Analisa regresi linier berganda digunakan untuk mengetahui pengaruh variabel bebas $(\mathrm{X})$ dan variabel terikat $(\mathrm{Y})$, dengan $\mathrm{X}_{1}$ adalah kualitas produk, $\mathrm{X}_{2}$ kualitas pelayanan dan $\mathrm{Y}$ adalah kepuasan pelanggan.

Analisis dijalankan dengan melakukan tabulasi jawaban responden pada kuesioner yang telah dijalankan. Maka dilakukan perhitungan menggunakan program SPSS untuk memperoleh nilai a dan b dengan notasi sebagai berikut:

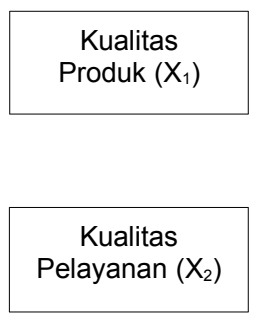

Tabel 3

Hasil Uji Regresi Liniear Berganda

\begin{tabular}{|c|c|c|c|}
\hline \multirow[t]{2}{*}{ Model } & \multicolumn{2}{|c|}{$\begin{array}{c}\text { Unstandardized } \\
\text { Coefficients }\end{array}$} & $\begin{array}{l}\text { Standardized } \\
\text { Coefficients }\end{array}$ \\
\hline & $B$ & Std. Error & Beta \\
\hline (Constant) & 3,781 & 4,836 & \\
\hline $1 \quad \begin{array}{l}\text { Kualitas } \\
\text { Produk }\end{array}$ & ,180 & ,057 & ,365 \\
\hline $\begin{array}{l}\text { Kualitas } \\
\text { Pelayanan }\end{array}$ & ,256 & ,054 & ,552 \\
\hline
\end{tabular}

Sumber: data primer hasil pengolahan data SPSS versi 20 (2017)

Berdasarkan hasil pengolahan data pada tabel 21 di atas, diperoleh model persamaan $\hat{\mathrm{Y}}_{(\mathrm{Z})}=3,781+$ $0,180 \mathrm{X}_{1}+0,256 \mathrm{X}_{2}$, artinya terdapat pengaruh positif antara kualitas produk dan kualitas pelayanan terhadap kepuasan pelanggan pada Bengkel Sisam Pematangsiantar.

b) Pengaruh Kualitas Produk Terhadap Kepuasan Pelanggan

Analisis regresi linier sederhana dalam penelitian ini digunakan untuk mengetahui pengaruh antara kualitas produk $\left(\mathrm{X}_{1}\right)$ terhadap kepuasan pelanggan (Y). Dengan menggunakan program SPSS versi 20, maka diperoleh hasil pengujian sebagai berikut:

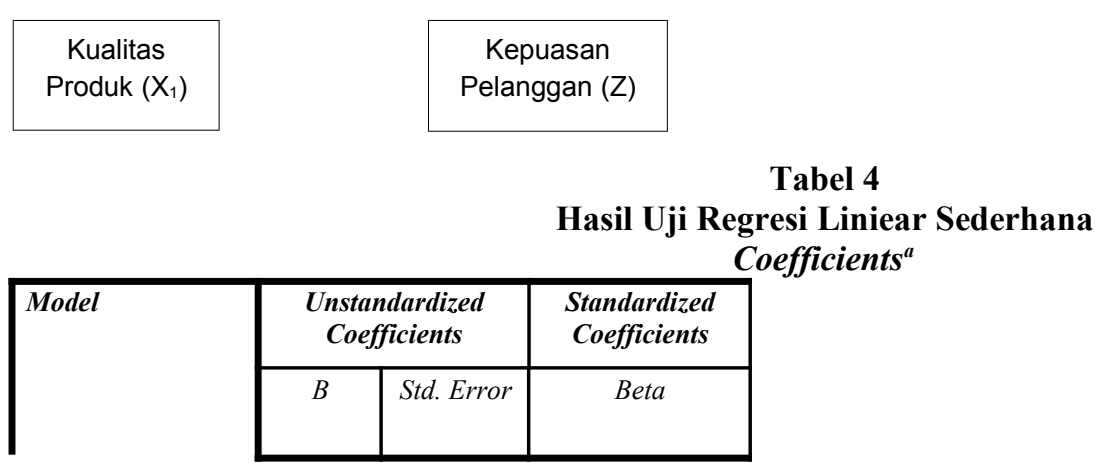




\begin{tabular}{|c|c|c|c|}
\hline $1 \quad \begin{array}{l}\text { (Constant) } \\
\begin{array}{l}\text { Kualitas } \\
\text { Produk }\end{array}\end{array}$ & 2,303 & 6,049 & 688, \\
\hline
\end{tabular}

Sumber: data primer hasil pengolahan data SPSS versi 20 (2017)

Berdasarkan hasil pengolahan data pada tabel 22 di atas, diperoleh model persamaan $\hat{Y}_{(\mathrm{Z})}=2,303+$ $0,339 \mathrm{X}_{1}$, artinya terdapat pengaruh positif antara kualitas produk terhadap kepuasan pelanggan pada Bengkel Sisam Pematangsiantar.

c. Pengaruh Kualitas Pelayanan Terhadap Kepuasan Pelanggan

Analisis regresi linier sederhana dalam penelitian ini digunakan untuk mengetahui pengaruh antara kualitas pelayanan $\left(\mathrm{X}_{2}\right)$ terhadap kepuasan pelanggan (Y). Dengan menggunakan program SPSS versi 20, maka diperoleh hasil pengujian sebagai berikut:

\begin{tabular}{|c|c|}
\hline Kualitas \\
Pelayanan $\left(\mathrm{X}_{2}\right)$ & $\begin{array}{c}\text { Kepuasan } \\
\text { Pelangggan }(\mathrm{Z})\end{array}$ \\
\hline
\end{tabular}

Tabel 5

Hasil Uji Regresi Liniear Sederhana

\begin{tabular}{|c|c|c|c|}
\hline \multirow[t]{2}{*}{ Model } & \multicolumn{2}{|c|}{$\begin{array}{c}\text { Unstandardized } \\
\text { Coefficients }\end{array}$} & \multirow{2}{*}{$\begin{array}{c}\begin{array}{c}\text { Standardized } \\
\text { Coefficients }\end{array} \\
\text { Beta }\end{array}$} \\
\hline & $B$ & Std. Error & \\
\hline \multirow{2}{*}{$\begin{array}{ll} & \text { (Constant) } \\
1 & \text { Kualitas } \\
\text { Pelayanan }\end{array}$} & 16,592 & 2,895 & \\
\hline &, 355 & ,048 & ,766 \\
\hline
\end{tabular}

Sumber: data primer hasil pengolahan data SPSS versi 20 (2017)

Berdasarkan hasil pengolahan data pada tabel 23 di atas, diperoleh model persamaan $\hat{Y}_{(\mathrm{Z})}=16,592+$ $0,355 \mathrm{X}_{2}$, artinya terdapat pengaruh positif antara kualitas pelayanan terhadap kepuasan pelanggan pada Bengkel Sisam Pematangsiantar.

\section{d. Pengaruh Kepuasan Terhadap Loyalitas Pelanggan}

Penelitian ini memiliki tujuan untuk menganalisa pengaruh kepuasan pelanggan terhadap loyalitas pada Bengkel Sisam Pematangsiantar. Analisa data dalam penelitian ini menggunakan analisa regresi linier sederhana. Analisa regresi linier sederhana digunakan untuk mengetahui pengaruh variabel bebas $(\mathrm{X})$ dan variabel terikat $(\mathrm{Y})$, dengan $\mathrm{X}$ adalah kepuasan pelanggan dan Y loyalitas pelanggan.

Analisa dijalankan dengan melakukan tabulasi jawaban responden pada kuesioner yang telah dijalankan. maka dilakukan perhitungan menggunakan program aplikasi SPSS untuk memperoleh nilai a dan b dengan notasi sebagai berikut:

\begin{tabular}{|c|c|}
\hline $\begin{array}{c}\text { Kepuasan } \\
\text { Pelanggan }(\mathrm{Z})\end{array}$ & Loyalitas \\
Pelanggan $(\mathrm{Y})$
\end{tabular}

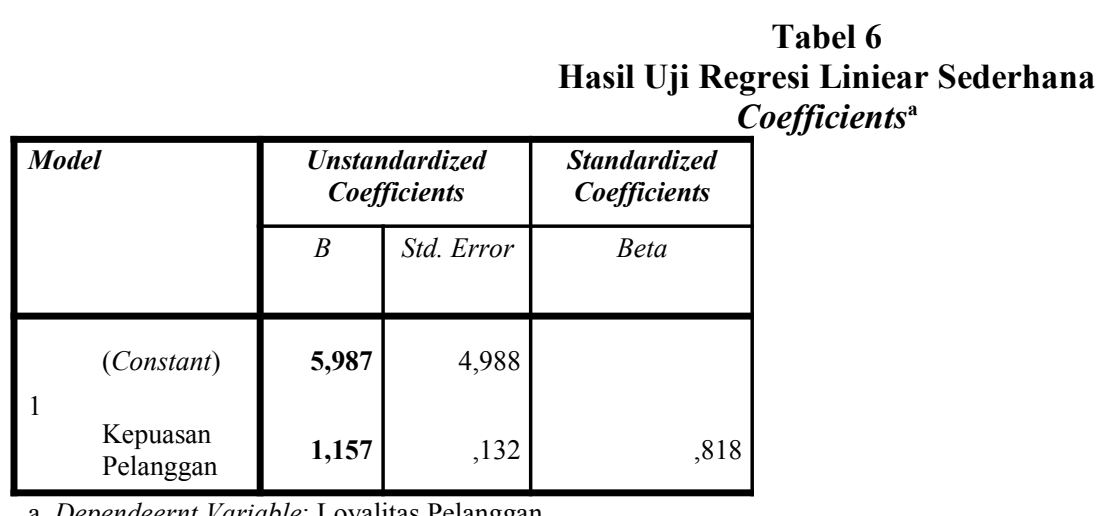

Sumber: data primer hasil pengolahan data SPSS versi 20 (2017)

Berdasarkan hasil pengolahan data pada tabel 24 di atas, diperoleh model persamaan $\hat{Y}=5,987+1,157 \mathrm{Z}$, artinya terdapat pengaruh yang positif antara kepuasan pelanggan terhadap loyalitas pelanggan pada Bengkel Sisam Pematangsiantar.

\section{2) Analisis Korelasi dan Determinasi}

a) Hubungan Kualitas Produk dan Kualitas Pelayanan Terhadap Kepuasan Pelanggan

Pada pengujian inidihitung secarakeseluruhanantaravariabelbebas $\mathrm{X}_{1}$ dan $\mathrm{X}_{2}$ terhadap variabelmediasi Z.Untukmengukurseberapabesarvariabel bebasX1dan $\mathrm{X}_{2}$ menjelaskan variabel Zmakadigunakan koefisien determinasi (KD). Berikut ini adalah hasil uji koefisien korelasi dan koefisien determinasisecara simultan antara variabelbebaskualitas produk $\left(\mathrm{X}_{1}\right)$ dankualitas pelayanan $\left(\mathrm{X}_{2}\right)$ dengan variabelmediasi loyalitas pelanggan (Z).Denganmenggunakan bantuan program SPSS Versi 20, didapatkan hasil perhitungan koefisien korelasi sebagai berikut:

Tabel 7 
Hasil Koefisien Korelasi dan Determinasi Model Summary ${ }^{\mathrm{b}}$

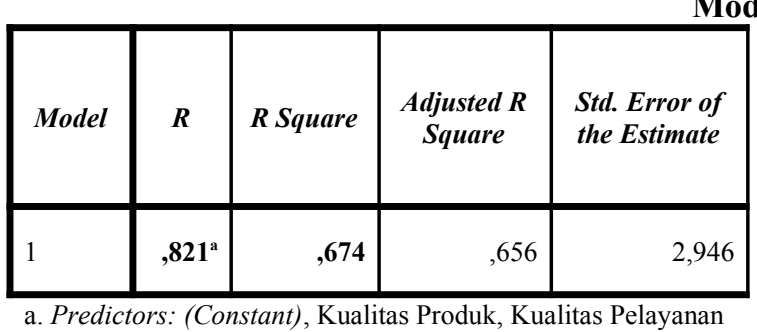

Predictors: (Constant), Kualitas Produk, Kualitas Pelayanan

b. Dependent Variable: Kepuasan Pelanggan

Sumber: hasil pengolahan data SPSS versi. 20 (2017)

Berdasarkan hasil koefisien korelasi pada tabel 25 di atas diperoleh nilai $r=0,821$, yang artinya terdapat hubungan yang sangat kuat dan positif antara kualitas produk dan kualitas pelayanan dengan kepuasan pelanggan pada Bengkel Sisam Pematangsiantar, sesuai dengan kriteria koefisien korelasi.

Kemudian diperoleh nilai koefisien determinasi $(\mathrm{R}$ Square $)=0,674$, artinya tinggi rendahnya kepuasan pelanggan pada Bengkel Sisam Pematangsiantar sebesar 67,4\% dapat dijelaskan oleh kualitas produk dan kualitas pelayanan, sedangkan untuk sisanya sebesar 32,6\% dipengaruhi oleh faktor lain seperti penetapan harga, citra merek, promosi, keputusan pembelian dan sebagainya yang tidak dibahas dalam penelitian ini.

\section{b) Hubungan Kualitas Produk Terhadap Kepuasan Pelanggan}

Pada tahap ini akan dihitung korelasi berupa derajat atau kedalaman hubungan fungsional yang menjelaskan hubungan antara perubahan, disebut dengan koefisien yang disimbolkan dengan $\mathrm{r}$. Pada pengujian ini dihitung hubungan variabel bebas $\left(\mathrm{X}_{1}\right)$ terhadap variabel terikat $(\mathrm{Y})$. Untuk mengukur seberapa besar variabel $\left(\mathrm{X}_{1}\right)$ menjelaskan variabel $(\mathrm{Y})$ maka digunakan koefisien korelasi dan koefisien determinasi antara variabel kualitas produk $\left(\mathrm{X}_{1}\right)$ dengan variabel kepuasan pelanggan $(\mathrm{Y})$. Dengan menggunakan bantuan program SPSS versi 20, didapatkan hasil perhitungan koefisien korelasi sebagai berikut:

Tabel 8

Hasil Koefisien Korelasi dan Determinasi Model Summary ${ }^{\mathrm{b}}$

\begin{tabular}{|c|r|r|r|r|}
\hline Model & $\boldsymbol{R}$ & $\boldsymbol{R}$ Square & $\begin{array}{c}\text { Adjusted } \\
\boldsymbol{R} \text { Square }\end{array}$ & $\begin{array}{c}\text { Std. Error of the } \\
\text { Estimate }\end{array}$ \\
\hline 1 &, $\mathbf{6 8 8}^{\mathrm{a}}$ &, $\mathbf{4 7 4}$ &, 460 & 3,69225 \\
\hline
\end{tabular}

Sumber: hasil pengolahan data SPSS versi 20 (2017)

Dari tabel di atas diperoleh korelasi nilai $r=0,688$ artinya terdapat hubungan yang cukup kuat dan positif antara kualitas produk dengan kepuasan pelanggan pada Bengkel Sisam Pematangsiantar. Diperoleh nilai koefisien determinasi (KD) 0,474 artinya tinggi rendahnya suatu kepuasan pelanggan pada Bengkel Sisam Pematangsiantar sebesar 47,4\% dapat di jelaskan oleh kualitas produk, sedangkan sisanya 52,6\% dipengaruhi oleh faktor lain seperti penetapan harga, citra merek, promosi, keputusan pembelian dan sebagainya yang tidak dibahas dalam penelitian ini.

\section{c) Hubungan Kualitas Pelayanan Terhadap Kepuasan Pelanggan}

Pada pengujian ini dihitung hubungan variabel bebas $\left(\mathrm{X}_{2}\right)$ terhadap variabel terikat $(\mathrm{Y})$. Untuk mengukur seberapa besar variabel $\left(\mathrm{X}_{2}\right)$ menjelaskan variabel $(\mathrm{Y})$ maka digunakan koefisien korelasi dan koefisien determinasi antara variabel kualitas pelayanan $\left(\mathrm{X}_{2}\right)$ dengan variabel kepuasan pelanggan $(\mathrm{Y})$. Dengan menggunakan bantuan program SPSS versi 20, didapatkan hasil perhitungan koefisien korelasi sebagai berikut:

Tabel 9

Hasil Koefisien Korelasi dan Determinasi Model Summary ${ }^{\mathrm{b}}$

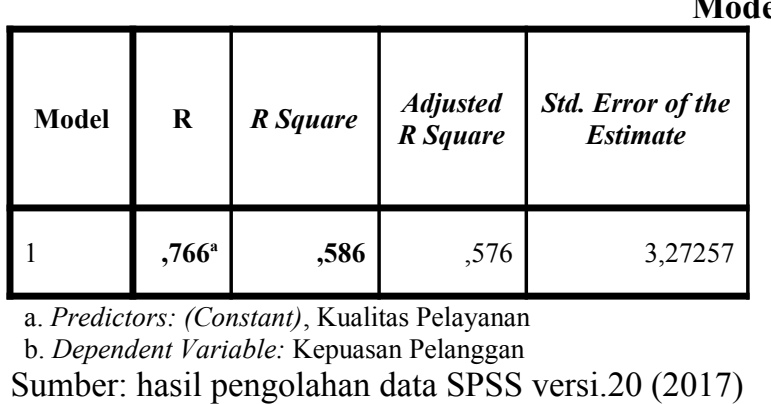

Dari tabel di atas diperoleh korelasi nilai $r=0,766$ artinya terdapat hubungan yang kuat dan positif antara kualitas pelayanan dengan kepuasan pelanggan pada Bengkel Sisam Pematangsiantar. Diperoleh nilai koefisien determinasi (KD) 0,586 artinya tinggi rendahnya suatu kepuasan pelanggan pada Bengkel Sisam Pematangsiantar sebesar 57,6\% dapat di jelaskan oleh kualitas produk, sedangkan sisanya 42,4\% dipengaruhi oleh faktor lain seperti penetapan harga, citra merek, promosi, keputusan pembelian dan sebagainya yang tidak dibahas dalam penelitian ini.

\section{d) Hubungan Kepuasan Pelanggan Terhadap Loyalitas Pelanggan}

Pada pengujian ini dihitung hubungan variabel mediasi (Z) kepuasan pelanggan terhadap variabel independent (Y) Untukmengukurseberapabesarvariabel $\mathrm{Z}$ menjelaskan variabel Ymakadigunakan koefisien determinasi (KD). Berikut ini adalah hasil uji koefisien korelasi dan koefisien determinasiantara 
variabelKepuasan pelanggan $(\mathrm{Z})$ dengan variabel loyalitas pelanggan (Y).Denganmenggunakan bantuan program SPSSversi 20, didapatkan hasil perhitungan koefisien korelasi sebagai berikut:

\section{Tabel 10}

Hasil Koefisien Korelasi dan Determinasi

\begin{tabular}{|c|c|r|r|r|}
\hline Model & $\boldsymbol{R}$ & $\boldsymbol{R}$ Square & $\begin{array}{l}\text { Adjusted } \\
\boldsymbol{R} \text { Square }\end{array}$ & $\begin{array}{l}\text { Std. Error of } \\
\text { the Estimate }\end{array}$ \\
\hline 1 &, $\mathbf{8 1 8}$ &, $\mathbf{6 7 0}$ &, 661 & 4,136 \\
\hline
\end{tabular}

a. Predictors: (Constant), Kepuasan Pelanggan

b. Dependent Variable: Loyalitas Pelanggan

Sumber: hasil pengolahan data SPSS versi.20 (2017)

'Berdasarkan hasil koefisien korelasi pada tabel 28 di atas diperoleh nilai r 0,818, yang artinya terdapat hubungan yang sangat kuat dan positif antara kepuasan pelanggan dengan loyalitas pelanggan pada Bengkel Sisam Pematangsiantar, sesuai dengan kriteria koefisien korelasi pada tabel 6. Kemudian diperoleh nilai koefisien determinasi (R Square) =0,670 artinya baik tidaknya loyalitas pelanggan pada Bengkel Sisam Pematangsiantar sebesar $67 \%$ dapat dijelaskan oleh kepuasan pelanggan, sedangkan sisanya sebesar 33\% di dipengaruhi oleh faktor lain seperti penetapan harga, citra merek, promosi, keputusan pembelian dan sebagainya yang tidak dibahas dalam penelitian ini.

\section{3) Uji Hipotesis}

a) Hipotesis 1

Pengaruh Kualitas Produk dan Kualitas Pelayanan terhadap Kepuasan Pelanggan secara simultan

Pengujian ini dilakukan secara simultan yaitu untuk menentukan diterima atau ditolaknya hipotesis, pengujian hipotesis dengan kriteria jika $F_{\text {hitung }}>F_{\text {tabel }}$ atau signifikan $\leq 0,05$ maka $\mathrm{H}_{0}$ ditolak. Untuk menguji kebenarannya maka dilakukan pengujian hipotesis dengan menggunakan program SPSS versi 20.

Tabel 11

Perkiraan Nilai $\mathbf{F}_{\text {hitung }}$

\begin{tabular}{|l|r|r|r|r|r|}
\hline Model & \multicolumn{1}{|c|}{$\begin{array}{c}\text { Sum of } \\
\text { Squares }\end{array}$} & Df & $\begin{array}{c}\text { Mean } \\
\text { Square }\end{array}$ & $\boldsymbol{F}$ & Sig. \\
\hline Regression & 662,867 & 2 & 331,433 & $\mathbf{3 8 , 1}$ & $\mathbf{0 0 0}^{\mathrm{b}}$ \\
1 Residual & 321,133 & 37 & 8,679 & & \\
Total & 984,000 & 39 & & & \\
\hline
\end{tabular}

a. Dependent Variable: Kepuasan Pelanggan

b. Predictors: (Constant), Kualitas Produk, Kualitas Pelayanan

Sumber: hasil pengolahan data dengan SPSS versi 20 (2017)

Berdasarkan tabel di atas diperoleh nilai $F_{\text {hitung }}$ sebesar 38,187 $>F_{\text {tabel }}$ dengan $(0,05: 2$ vs 37) $(40-2-1=37)$ sebesar 3,25, atau dengan signifikan $0,000<\alpha 0,05$, maka $\mathrm{H}_{0}$ ditolak, artinya kualitas produk dan kualitas pelayanan berpengaruh positif dan signifikan terhadap kepuasan pelanggan pada Bengkel Sisam Pematangsiantar.

\section{b) Hipotesis 2}

Pengaruh Kualitas Produk dan Kualitas Pelayanan terhadap Kepuasan Pelanggan secara parsial

Pengujian ini dilakukan secara parsial yaitu untuk menentukan diterima atau ditolaknya hipotesis, pengujian hipotesis dilakukan dengan kriteria jika $t_{\text {hitung }}>t_{\text {tabel }}$ atau signifikansi $\leq 0,05$ maka $\mathrm{H}_{0}$ ditolak. Untuk menguji kebenarannya maka dilakukan pengujian hipotesis dengan menggunakan program aplikasi SPSS versi 20. Berikut ditampilkan tabel mengenai perkiraan nilai $\mathrm{t}_{\text {hitung }}$ untuk $\mathrm{X}_{1}$ (kualitas produk) dan variabel $\mathrm{X}_{2}$ (kualitas pelayanan) terhadap Z (kepuasan pelanggan).

Tabel 12

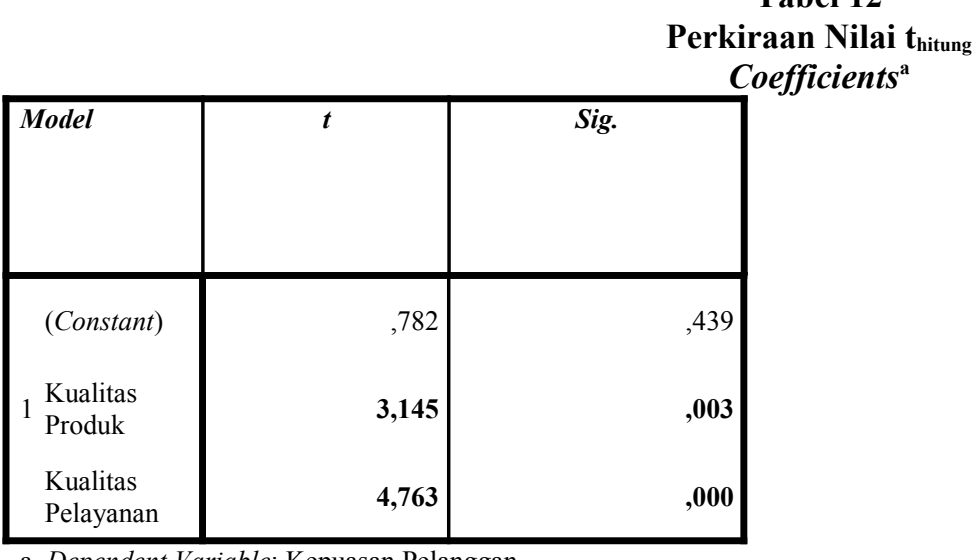

a. Dependent Variabl

Sumber: hasil pengolahan data dengan SPSS versi 20 (2017)

Berdasarkan tabel 30 di atas, diperoleh.

(1) Nilai thitung pada variabel kualitas produk sebesar 3,145 $>$ dari tabel dengan $\mathrm{df}=\mathrm{n}-\mathrm{k}-1 \quad(40-2-1=37)$ sebesar 2,026 atau taraf signifikan $0,003<\alpha 0,05$ maka $\mathrm{H}_{0}$ ditolak, artinya kualitas produk berpengaruh positif dan signifikan terhadap kepuasan pelanggan pada Bengkel Sisam Pematangsiantar.

(2) Nilai $t_{\text {hitung }}$ pada variabel kualitas pelayanan sebesar 4,763 $>$ dari $t_{\text {tabel }}$ dengan $\mathrm{df}=\mathrm{n}-\mathrm{k}-1,(40-2-1=37)$ sebesar 2,026 atau taraf signifikan $0,000<\alpha 0,05$, maka $\mathrm{H}_{0}$ ditolak, artinya kualitas pelayanan berpengaruh positif dan signifikan terhadap kepuasan pelanggan pada Bengkel Sisam Pematangsiantar.

c) Hipotesis 3 


\section{Pengaruh Kepuasan Pelanggan Terhadap Loyalitas Pelanggan}

Pengujian ini dilakukan secara parsial yaitu dilakukan untuk menentukan diterima atau ditolaknya hipotesis, pengujian hipotesis dengan kriteria jika $t_{\text {hitung }}>t_{\text {tabel }}$ atau signifikansi $\leq \alpha 0,05$ maka $\mathrm{H}_{0}$ di tolak. Untuk menguji kebenarannya maka dilakukan pengujian hipotesis dengan menggunakan program aplikasi SPSS versi 20. Berikut ditampilkan tabel mengenai perkiraan $t_{\text {hitung }}$ untuk variabel $\mathrm{Z}$ (kepuasan pelanggan) terhadap $\mathrm{Y}$ (loyalitas pelanggan).

Tabel 13

Perkiraan Nilai $t_{\text {hitung }}$ Coefficients $^{a}$

\begin{tabular}{|c|c|c|}
\hline Model & $T$ & Sig. \\
\hline $\begin{array}{ll} & (\text { Constant }) \\
& \\
& \text { Kepuasan } \\
\text { Pelanggan }\end{array}$ & 1,200 & $\begin{array}{l}, 237 \\
, 000\end{array}$ \\
\hline
\end{tabular}

a. Dependent Variable: Loyalitas Pelanggan

Sumber: hasil pengolahan data dengan SPSS versi 20 (2017)

Berdasarkan tabel 31 di atas, diperoleh nilai $t_{\text {hitung }}$ pada variabel kepuasan pelanggan sebesar 8,775 $>$ dari

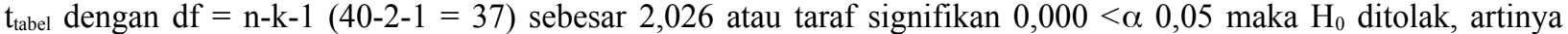
kepuasan pelanggan berpengaruh positif dan signifikan terhadap loyalitas pelanggan pada Bengkel Sisam Pematangsiantar.

\section{Evaluasi}

\section{a. Kualitas Produk pada Bengkel Sisam Pematangsiantar}

Kualitas produk sangat mempengaruhi kinerja dan kehandalan mesin sepeda motor. kualitas produk pada Bengkel Sisam Pematangsiantar dapat dikatakan sangat baik, hal ini dapat dilihat dari hasil kuesioner yang dibagikan kepada responden yang secara keseluruhan diperoleh nilai rata-rata 4,32 dengan kriteria jawaban sangat baik.

Namun ada beberapa aspek yang dinilai baik tetapi masih ada yang dibawah rata-rata indikator lain, yang pertama yaitu pada dimensi kinerja dengan indikator karakteristik utama produk mesin sepeda motor yang telah direparasi bernilai rata-rata 4,28 dengan kriteria nilai jawaban sangat baik, cara meningkatkannya karyawan sebaiknya lebih meningkatkan pengetahuannya dalam setiap setelan mesin. Pada indikator daya guna produk mesin sepeda motor yang telah direparasi bernilai rata-rata 4,20 dengan kriteria nilai jawaban baik, cara meningkatkannya adalah karyawan sebaiknya lebih fokus dalam bekerja, sehingga mesin yang direparasinya menjadi lebih handal.

Pada dimensi keistimewaan dengan indikator perkembangan produk mesin sepeda motor diperoleh nilai rata-rata 4,05 dengan kriteria nilai jawaban baik, cara meningkatkannya adalah pimpinan sebaiknya memikirkan stelan mesin sepeda motor yang akan datang, karena semakin tahun sepeda motor selalu berinovasi baik dari segi penampilan dan segi mesin yang ada pada sepeda motor tersebut.

Pada dimensi kehandalan dengan indikator kinerja fungsi dari produk mesin sepeda motor diperoleh nilai rata-rata 4,28 dengan kriteri nilai jawaban sangat baik, cara meningkatkannya adalah para karyawan sebaiknya menambah pengetahuan terhadap kemauan mesin sepeda motor.

Pada dimensi kesesuaian dengan spesifikasi dengan indikator pemenuhan standart produk diperoleh nilai rata-rata 4,28 dengan kriteria nilai jawaban sangat baik, cara meningkatkannya sebaiknya pimpinan memilih barang yang berkualitas standart nasional dan terjamin kualitasnya. Pada indikator keinginan konsumen diperoleh nilai ratarata 4,20 dengan kriteria nilai jawaban baik, cara meningkatkannya adalah para karyawan sebaiknya membantu para pelanggan dan menganjurkan untuk menggunakan produk yang memiliki kualitas yang tinggi.

Pada dimensi daya tahan dengan indikator ukuran ketahanan produk mesin yang telah direparasi diperoleh nilai rata-rata 4,05 dengan kriteria nilai jawaban baik, cara meningkatkannya adalah pimpinan maupun karyawan Bengkel Sisam sebaiknya lebih menjaga kualitas bahan baku maupun kualitas reparasiannya.

Pada dimensi kemampuan pelayanan dengan indikator kompetensi pelayanan diperoleh nilai rata-rata 4,28 dengan kriteria nilai jawaban sangat baik, cara meningkatkannya sebaiknya lebih dekat dengan pelanggan untuk menerima keluhan dan keinginan pelanggan.

Pada dimensi estetika dengan indikator daya tarik diperoleh nilai rata-rata 4,28 dengan kriteria nilai jawaban sangat baik, cara meningkatkannya sebaiknya lebih jeli dan teliti dalam pembubutan. Pada indikator kemudahan produk diperoleh nilai rata-rata 4,28 dengan kriteria nilai jawaban sangat baik, cara meningkatkannya adalah pimpinan sebaiknya memperhatikan kerja karyawan dalam proses pembubutan.

Pada dimensi kualitas yang dipersiapkan dengaan indikator citra merek diperoleh nilai rata-rata 4,23 dengan kriteria nilai jawaban sangat baik, cara meningkatkannya sebaiknya pimpinan dan karyawan bekerja sama dalam meningkatkan kualitas Bengkel Sisam. Pada indikator perasaan konsumen diperoleh nilai rata-rata 4,20 dengan kriteria nilai jawaban baik, cara meningkatkannya adalah pimpinan menjaga hubungan baik terhadap pelanggan.

Dalam hal ini dapat dilihat bahwa kualitas produk pada Bengkel Sisam Pematangsiantar sudah dikategorikan sangat baik, walaupun sudah dikategorikan sangat baik, para karyawan dan pimpinan sebaiknya selalu menjaga kualitas produk untuk menciptakan kualitas produk yang bermutu.

\section{b. Kualitas Pelayanan pada Bengkel Sisam Pematangsiantar}

Kualitas pelayanan merupakan salah satu hal yang terpenting dalam menarik pelanggan, apabila kualitas pelayanan karyawan dalam sebuah perusahaan sudah baik, maka akan menjadi sebuah keuntungan bagi perusahaan. Berdasarkan hal tersebut kualitas pelayanan pada Bengkel Sisam Pematangsiantar dikatakan baik, hal ini dapat dilihat dari jawaban responden dengan nilai keseluruhan rata-rata sebesar 3,92 dengan kriteria jawaban baik.

Namun tentunya ada beberapa indikator yang perlu diperhatikan karena nilainya masih dibawah rata-rata, seperti pada dimensi reability (kehandalan) dengan indikator kehandalan tepat waktu diperoleh nilai rata-rata 3,78 
dengan kriteria nilai jawaban baik, cara meningkatkanya sebaiknya pimpinan Bengkel Sisam menambah karyawan. Pada indikator pelayanan yang akurat berada pada rata-rata 3,75 dengan kriteria nilai jawaban baik, cara meningkatkanya adalah karyawan sebaiknya lebih detail dalam menjelaskan solusi terhadap pelanggan.

Pada dimensi assurance (jaminan) dengan indikator jaminan barang yang diberikan berada pada rata-rata 3,78 dengan kriteria nilai jawaban baik, cara meningkatkanya sebaiknya pimpinan menambahkan jangka waktu garansi. Pada indikator kemampuan mekanik berada pada rata-rata 3,75 dengan kriteria jawaban nilai baik, cara meningkatkannya sebaiknya para karyawan menambah pengetahuannya. Pada indikator kemampuan administrasi berada pada rata-rata 3,78 dengan kriteria nilai jawaban baik, cara meningkatkannya sebaiknya karyawan belajar lebih mengenal produk spare part.

Pada dimensi emphaty dengan indikator tanggung jawab perusahaan terhadap produk yang kembali rusak dalam jangka waktu terdekat berada pada rata-rata 3,63 dengan kriteria nilai jawaban baik, cara meningkatkannya sebaiknya karyawan lebih teliti dalam mereparasi mesin agar tidak terjadi kerusakan kembali dalam waktu tertentu. Pada indikator perhatian terhadap kebutuhan pelanggan berada pada rata-rata 3,53 dengan kriteria nilai jawaban baik, cara meningkatkannya sebaiknyakaryawan berinteraksi kepada pelanggan dengan baik untuk mengetahui kebutuhan apa saja yang dibutuhkannya.

Dalam hal ini dapat dilihat bahwa kualitas pelayanan pada Bengkel Sisam Pematangsiantar sudah dikategorikan baik. Walaupun sudah dikategorikan baik alangka lebih baiknya jika para karyawan sebaiknya lebih memperhatikan sifat ataupun karakter pelanggan agar pelanggandapat merasakan pelayanan yang berkualitas.

\section{c. Kepuasan Pelanggan pada Bengkel Sisam Pematangsiantar}

Kepuasan pelanggan merupakan suatu keadaan dimana keinginan, harapan dan kebutuhan pelanggan dapat terpenuhi. Pelayanan yang memuaskan pada dasarnya berusahan untuk dapat memenuhi kebutuhan dan harapan pelanggan. Berdasarkan dimensi yang digunakan dan hasil penelitian yang diperoleh dapat dijelaskan bahwa kepuasan pelanggan pada Bengkel Sisam Pematangsiantar berada pada rata-rata 4,17 dengan kriteria baik.

Namun dari nilai rata-rata ada beberapa indikator yang dianggap masih dibawa nilai rata-rata. Dimensi emosi yang diamati dengan tercapainya perasaan konsumen mengenai kemampuan produk untuk memenuhi kebutuhan pelanggan diperoleh nilai rata-rata 3,90 dengan kriteria jawaban puas, cara meningkatkannya sebaiknya pimpinan dan karyawan sebaiknya berinovasi untuk meningkatkan yang terbaik bagi perusahaa, baik itu dari segi kualitas produk maupun pelayanan yang diberikan kepada pelanggan.

Pada dimensi harga dengan indikator harga yang diberikan kepada pelanggan diperoleh nilai rata-rata 4,00 dengan kriteria jawaban puas, cara meningkatkannya sebaiknya pimpinan tidak mengambil keuntungan yang terlalu tinggi. Pada indikator keterjangkauan harga diperoleh nilai rata-rata 4,00 dengan kriteria jawaban puas, cara meningkatkannya sebaiknya pimpinan memberikan pilihan variasi harga sesuai dengan kualitas produk dan keterjangkauan pelanggan. Pada indikator intensitas pemberian diskon diperoleh nilai rata-rata 3,98 dengan kriteria jawaban baik, cara mengatasinya sebaiknya pimpinan Bengkel Sisam memberikan lebih banyak produk spare part yang didiskonkan.

Dalam hal ini dapat dilihat bahwa kepuasan pelanggan pada Bengkel Sisam Pematangsiantar sudah dikategorikan baik. Walaupun sudah dikategorikan baik hendaknya pimpinan dan karyawan bekerja sama untuk dan berupaya memenuhi keinginan pelanggan sesuai dengan yang diharapkannya sehingga kepuasan pelanggan dapat terpenuhi.

\section{d. Loyalitas Pelanggan pada Bengkel Sisam Pematangsiantar}

Loyalitas pelanggan adalah komitment yang kuat dari pelanggan untuk berlangganan kembali atau melakukan pembelian ulang produk/jasa yang disukai secara konsisten di masa yang akan datang, meskipun pengaruh situasi dan usaha-usaha pemasaran mempunyai potensi untuk menimbulkan perilaku berpindah. Berdasarkan dimensi yang digunakan dan hasil penelitian yang diperoleh dapat dijelaskan bahwa loyalitas pelanggan yang ada pada Bengkel Sisam Pematangsiantar dikatakan baik, hal ini dapat dilihat dari nilai rata-rata 4,11 .

Namun ada beberapa aspek yang dinilai baik tetapi masih ada yang dibawah rata-rata indikator lain, yang pertama yaitu pada dimensi membeli antar lini produk dan jasa pada indikator kelengkapan jenis perawatan atau pembetulan mesin sepedamotor diperoleh nilai rata-rata 3,98 dengan kriteria nilai jawaban baik, cara mengatasinya adalah memperbaharui mesin bubutan yang lebih canggih yang dapat menambah jenis pembetulan mesin sepeda motor.

Pada dimensi merekomendasikan kepada orang lain pada indikator tingkat kepuasan pelanggan diperoleh nilai rata-rata 4,05 dengan kriteria nilai jawaban baik, cara meningkatkannya sebaiknya para pimpinan menyarankan kepada pelanggan untuk memberitahukan kepada kerabat maupun keluarga atas produk maupun jasa Bengkel Sisam. Pada indikator kesopanan diperoleh nilai rata-rata 3,85 dengan kriteria nilai jawaban baik, cara meningkatkannya sebaiknya pimpinan dan karyawan sebaiknya lebih baik dalam berinteraksi dengan pelanggan dan tidak memandang status dari pelanggan.

Pada dimensi menunjukan kekebalan kepada pesaing pada indikator keinginan membeli produk atau jasa pada satu tempat diperoleh nilai rata-rata 4,08 dengan kriteria nilai jawaban baik, cara meningkatkanya sebaiknya pimpinan dan karyawan mempertahankan produk dan jasa yang berkualitas. Pada indikator percaya terhadap produk/jasa yang digunakan berada pada rata-rata 3,70 dengan kriteria nilai jawaban baik, cara meningkatkannya adalah karyawan sebaiknya meningkatkan kinerjanya untuk mendapatkan hasil produk yang berkualitas.

Dalam hal ini dapat dilihat bahwa loyalitas pelanggan pada Bengkel Sisam Pematangsiantar sudah dikategorikan baik. Walaupun sudah dikategorikan baik, karyawan dan pimpinan terus meningkatkan kualitas produk dan memberikan pelayanan yang baik kepada para pelanggan, agar para pelanggan menjadi semakin puas dan loyal terhadap perusahaan.

\section{KESIMPULAN DAN SARAN}

\section{Kesimpulan}

Berdasarkan seluruh uraian yang telah dikemukakan dalam bab sebelumnya, maka penulis menarik kesimpulan, yaitu sebagai berikut: 
a. Hasil analisis deskriptif kualitatif kualitas produk dengan nilai rata-rata adalah sebesar 4,32. Dengan nilai tertinggi terdapat pada dimensi kinerja dengan indikator aspek fungsional dari suatu produk, pada dimensi kesesuaian dengan spesifikasi dengan indikator kesesuai produk yang telah diberikan pada Bengkel Sisam berada pada rata-rata 4,60. Nilai terendah berada pada dimensi keistimewaan dengan indikator perkembangan produk, pada dimensi daya tahan dengan indikator ukuran ketahanan berada pada rata-rata 4,05.

b. Hasil analisis deskriptif kualitatif kualitas pelayanan dengan nilai rata-rata adalah sebesar 3,92. Dengan nilai tertinggi terdapat pada dimensi tangible (bukti fisik) dengan indikator perlengkapan mesin yang digunakan untuk mereparasi, pada dimensi reability (kehandalan) pada indikator pelayanan yang diberikan dengan cepat, pada dimensi responsiveness (ketanggapan) dengan indikator respon karyawan terhadap pelanggan berada pada rata-rata 4,18. Nilai terendah berada pada dimensi emphaty dengan indikator perhatian terhadap kebutuhan pelanggan bearada pada rata-rata 3,53.

c. Hasil analisis deskriptif kualitatif kepuasan pelanggan dengan nilai rata-rata 4,17. Dengan nilai tertinggi terdapat pada dimensi promosi pada indikator pemberian promo yang di berikan kepada pelanggan berada pada rata-rata 4,45. Nilai terendah berada pada dimensi emosi pada indikator tercapainya perasaan konsumen mengenai kemampuan produk memenuhi kebutuhan pelanggan berada pada rata-rata 3,90.

d. Hasil analisis deskriptif kualitatif loyalitas pelanggan dengan nilai rata-rata 4,11. Dengan nilai tertinggi terdapat pada dimensi melakukan pembelian berulang pada indikator harga yang di tetapkan Bengkel Sisam berada pada rata-rata 4,38. Nilai terendah terdapat pada dimensi menunjukan kekebalan terhadap pesaing pada indikator percaya terhadap produk/jasa yang digunakan berada pada rata-rata 3,70.

e. Kualitas produk $\left(\mathrm{X}_{1}\right)$ dan kualitas pelayanan $\left(\mathrm{X}_{2}\right)$ memiliki pengaruh yang positif terhadap kepuasan pelanggan (Z) Bengkel Sisam Pematangsiantar dibuktikan dengan hasil analisis regresi $\hat{\mathrm{Y}}_{(\mathrm{Z})}=3,781+0,180 \mathrm{X}_{1}+0,256 \mathrm{X}_{2}$. Kualitas produk $\left(\mathrm{X}_{1}\right)$ memiliki pengaruh yang positif terhadap kepuasan pelanggan (Z) Bengkel Sisam Pematangsiantar dibuktikan dengan hasil regresi $\hat{\mathrm{Y}}_{(\mathrm{Z})}=2,303+0,339 \mathrm{X}_{1}$. Kualitas pelayanan $\left(\mathrm{X}_{2}\right)$ memiliki pengaruh yang positif terhadap kepuasan pelanggan (Z) Bengkel Sisam Pematangsiantar dibuktikan dengan hasil regresi $\hat{\mathrm{Y}}_{(\mathrm{Z})}=16,592+0,355 \mathrm{X}_{2}$. Kepuasan pelanggan $(\mathrm{Z})$ memiliki pengaruh yang positif terhadap loyalitas pelanggan (Y) Bengkel Sisam Pematangsiantar yang dibuktikan dengan hasil regresi $\hat{\mathrm{Y}}=5,987+$ $1,157 \mathrm{Z}$

6. Kualitas produk $\left(\mathrm{X}_{1}\right)$ dan kualitas pelayanan $\left(\mathrm{X}_{2}\right)$ memiliki hubungan yang kuat dan positif dengan kepuasan pelanggan $(Z)$ Bengkel Sisam Pematangsiantar dibuktikan dengan korelasi nilai r sebesar 0,821 dan nilai koefisien determinasi (R Square) sebesar 0,674 (67,4\%). Kualitas produk $\left(\mathrm{X}_{1}\right)$ memiliki hubungan yang kuat dan positif dengan kepuasan pelanggan (Z) Bengkel Sisam Pematangsiantar dibuktikan dengan korelasi dengan nilai r sebesar 0,688 dan nilai koefisien determinasi (R Square) sebesar 0,474 (47,4\%). Kualitas pelayanan $\left(\mathrm{X}_{2}\right)$ memiliki hubungan yang kuat dan positif dengan kepuasan pelanggan (Z) Bengkel Sisam Pematangsiantar dibuktikan dengan korelasi dengan nilai r sebesar 0,766 dan nilai koefisien determinasai (R Square) sebesar $0,586(58,6 \%)$. Kepuasan pelanggan (Z) memiliki hubungan yang kuat dan positif dengan loyalitas pelanggan (Y) Bengkel Sisam Pematangsiantar dibuktikan dengan korelasi dengan nilai $r$ sebesar 0,818 dan nilai koefisien determinasi (R Square) sebesar 0,670 (67\%).

f. Kualitas produk dan kualitas pelayanan berpengaruh positif dan signifikan terhadap kepuasan pelanggan pada Bengkel Sisam Pematangsiantar secara simultan dibuktikan dengan hasil uji hipotesis 1 diperoleh nilai $F_{\text {hitung }}$ sebesar 38,187 sedangkan $F_{\text {tabel }}$ dengan $(0,05: 2$ vs 37) $(40-2-1=37)$ sebesar 3,25, atau dengan signifikan 0,000 $<\alpha 0,05$.

g. Kualitas produk berpengaruh positif dan signifikan terhadap kepuasan pelanggan pada Bengkel Sisam Pematangsiantar dibuktikan dengan hasil uji hipotesis 2 diperoleh nilai $t_{\text {hitung }}$ pada variabel $\mathrm{X}_{1}$ (kualitas produk) sebesar 3,145 $>$ dari $t_{\text {tabel }}$ dengan $\mathrm{df}=\mathrm{n}-\mathrm{k}-1 \quad(40-2-1=37)$ sebesar 2,026 atau taraf signifikan $0,003<\alpha 0,05$. Sedangkan kualitas pelayanan berpengaruh positif dan signifikan terhadap kepuasan pelanggan pada Bengkel Sisam Pematangsiantar secara parsial dibuktikan dengan hasil uji hipotesis pada variabel $\mathrm{X}_{2}$ (kualitas pelayanan) diperoleh nilai $\mathrm{t}_{\text {hitung }}$ sebesar $4,763>$ dari $\mathrm{t}_{\text {tabel }}$ dengan $\mathrm{df}=\mathrm{n}-\mathrm{k}-1,(40-2-1=37)$ sebesar 2,026 atau taraf signifikan $0,000<\alpha 0,05$.

9. Kepuasan pelanggan berpengaruh positif dan signifikan terhadap loyalitas pelanggan pada Bengkel Sisam Pematangsiantar secara parsial dibuktikan dengan hasil uji hipotesis 3 diperoleh nilai $t_{\text {hitung pada variabel } Z}$ (kepuasan pelanggan) sebesar $8,775>$ dari $t_{\text {tabel }}$ dengan $\mathrm{df}=\mathrm{n}-\mathrm{k}-1(40-2-1=37)$ sebesar 2,026 atau taraf signifikan $0,000<\alpha 0,05$.

\section{Saran}

Berdasarkan kesimpulan di atas, maka perlu dikemukakan beberapa saran yang dapat berguna bagi perusahaan, yaitu sebagai berikut:

a. Kualitas produk Bengkel Sisam Pematangsiantar masih perlu ditingkatkan, karena masi ada indikator yang belum optimal. Untuk meningkatkannya para karyawan dan pimpinan sebaiknya selalu menjaga kualitas bahan baku produk, meningkatkan pengetahuan karyawan dalam reparasi dan berinovasi dalam modifikasi mesin untuk menciptakan kepercayaan pelanggan atas kualitas produk Bengkel Sisam.

b. Kualitas pelayanan Bengkel Sisam Pematangsiantar masih perlu ditingkatkan, untuk itu pimpinan memberikan arahan kepada karyawan untuk lebih tanggap dalam menanggapi permasalahan pelanggan dan para karyawan sebaiknya lebih detail dalam menjelaskan solusi dari permasalahan pelanggan, serta melayani pelanggan dengan baik dan sopan agar pelanggan dapat merasakan pelayanan yang berkualitas.

c. Kepuasan pelanggan Bengkel Sisam Pematangsiantar masih perlu ditingkatkan, untuk itu pimpinan hendaknya memberikan harga yang terjangkau kepada pelanggan namun tidak mengurangi kualitas reparasi yang diberikan Bengkel Sisam. Sehingga kepuasan pelanggan dapat terpenuhi.

d. Loyalitas pelanggan Bengkel Sisam masih perlu dtingkatkan, karena masih ada beberapa indikator yang belum optimal. Untuk mengoptimalkannya Bengkel Sisam Pematangsiantar hendaknya pimpinan menyiapkan beberapa peratan mesin bubut yang canggih, memberikan produk dan jasa yang berkualitas tinggi, meningkatkan kinerja karyawan jauh lebih baik dan selalu melayani pelanggan dengan baik dan sopan agar para pelanggan menjadi semakin puas dan loyal terhadap perusahaan.

e. Sehubungan dengan keterbatasan-keterbatasan yang ada pada penulis, penelitian ini masih terdapat kelemahankelemahan dan belum dapat mengungkapkan seluruh variabel yang dapat mempengaruhi loyalitas pelanggan 
pada Bengkel Sisam Pematangsiantar. Sebagai bahan masukan untuk penelitian selanjutnya, perlu memperbanyak variabel penelitian, seperti penetapan harga, citra merek, promosi, dan lain-lain.

\section{E. DAFTAR PUSTAKA}

Gerson, Richard F. 2002. Mengukur Kepuasan Pelanggan. Jilid Kedua. Jakarta: Penerbit PPM.

Griffin, Jill. 2003. Costumer Loyalty. Jakarta: Penerbit Erlangga

Griffin, Ricky W. 2004. Costumer Loyalty, Menumbuhkan dan Mempertahankan Kestiaan Pelanggan. Jakarta: Penerbit Erlangga.

Handoko, T. Hani. 2009. Manajemen. Edisi Kedua. Yogyakarta: BPFE.

Irawan, Hendy. 2004. Kepuasan Pelayanan Jasa. Jakarta: Erlangga

Kotler, Philip dan Kevin, Lane Keller. 2009. Manajemen Pemasaran. Edisi Keduabelas. Jakarta: PT Indeks.

Kotler, Philip \& Gary Armstrong. 2008. Prinsip-Prinsip Pemasaran. Edisi Kedua belas. Jilid 1. Jakarta: Penerbit Erlangga.

Lupiyoadi, Rambat dan A. Hamdani. 2001. Manajemen Pemasaran Jasa. Jakarta: Penerbit Salemba Empat. 2006. Manajemen Pemasaran Jasa. Edisi 2. Jakarta: Penerbit Salemba Empat.

Robbins, Stephen P \& Mary Coutler. 2005. Manajemen. Jakarta: PT. Indeks Kelompok Gramedia.

Tjiptono, Fandy. 2008. Strategi Pemasaran. Edisi III. Yogyakarta: Penerbit Andi 